\title{
THE CRETACEOUS SANFRANCISCAN BASIN, EASTERN PLATEAU OF BRAZIL
}

\author{
GERALDO NORBERTO CHAVES SGARBI
}

\begin{abstract}
The Cretaceous Sanfranciscan Basin, located in the eastern plateau of Brazil, is one of the most impressive continental basin of the country, because of its complex and exceptional association of sedimentary and volcanic rocks. The presence of macro and microfossils, large diamonds and a surprising occurrence of a radiolarian fauna present in chert layers intercalated in eolian sandstones form very interesting topics on the tectonic and paleogeography aspects of the Gondwana during the Cretaceous.

The basin has a south-north elongated shape, from the west of Minas Gerais State (latitude $20^{\circ} \mathrm{S}$ ) to the southern Tocantins, Maranhao and Piaui States (latitude $10^{\circ} \mathrm{S}$ ). It is approximately $1100 \mathrm{~km}$ long and has a maximum width of about $270 \mathrm{Km}$ (Fig 1). It occurs in a corridor between $44^{\circ}$ and $47^{\circ}$ of longitude W. It was filled with Areado and Mata da Corda Groups, and lies over, from south to north, low-grade metamorphic sediments of the Bambuí Group (Upper Proterozoic), Permo-Carbonifeous glaciogenic sediments of Santa Fé Group, Archean granitoids of the regional basement and sedimentary rocks of the Paleozoic Parnaíba Basin, in its outermost northern border.

The early Cretaceous Areado Group has $200 \mathrm{~m}$ of maximum thickness. It lies over older rocks along a regional disconformity and comprises a basal conglomerate with transported ventifacts deposited in a desert environment, associated to fine-grained lacustrine sediments and eolian and fluviodeltaic sandstones of the Três Barras Formation.

The late Cretaceous Mata da Corda Group has $230 \mathrm{~m}$ of maximum thickness. It lies over the Areado Group along a local unconformity, and is composed by ultramafic alkaline rocks and volcaniclastic rocks of the Patos Formation.

Above the latitude $17^{\circ} \mathrm{S}$ until the north of the basin, occur the Urucuia Formation, considered by some authors as part of this formation (Braun 1970, Grossi Sad et al. 1971). It consists of a basal conglomerate with transported ventifacts, lacustrine, eolian and fluvio deltaic sediments. This sequence is very similar to those of the Areado Group and, as will be shown later, there is the possibility of this formation to be part of the early Cretaceous Areado Group and not part of the Mata da Corda Group.
\end{abstract}

Keywords: Sanfranciscan Basin, Cretaceous continental sedimentation, paleoclimates, paleodesert environment, epiclastic rocks, siliciclastic rocks, alkaline rocks

TECTONIC FRAMEWORK The tectonic framework of the Sanfranciscan Basin is not yet well defined, and large areas still remains without specific studies.The southern Sanfranciscan Basin in the western Minas Gerais state (between latitude $18^{\circ} 00^{\prime}$ and $20^{\circ} 00^{\prime} \mathrm{S}$ and longitude $46^{\circ} 00 \mathrm{~W}$ ) is positioned at the east border of the Alto do Paranaiba Uplift, a S-N elongated tectonic feature.

This arch was active during the Cretaceous and originated depressions which formed on the western side (filled by Cretaceous sediments and lavas of the Paraná Basin) and on the eastern side, filled by the studied Cretaceous sediments and lavas of the Sanfranciscan Basin. The eastern marginal depression was interpreted by Hasui \& Haralyi (1991), as developed under extensional regime, with reactivation of N-S major faults, one transfer fault and many NNESSW small accommodation faults.

The Alto do Paranaíba Uplift and the Sanfranciscan Basin were the places of alkaline intrusions and kimberlites diatremes, which represents the Alto do Paranaiba Alkaline-Kimberlite Province. Bouguer anomaly data reported by Hasui and Haralyi (1991) indicate the presence of important lineaments of a NW/SE set, crossing the southwestern half of the arch. The tectonic development was aborted during the Late Cretaceous and the basin is now elevated at about $1100-1150 \mathrm{~m}$.

At the north, in the southwestern Tocantins State $\left(12^{\circ} 00\right.$ latitude $\mathrm{S}$ and $46^{\circ} 30$ longitude $\mathrm{W}$ ), the Urucuia Formation overlies metasediments and granitoids rocks of the basement. Borges et al.(1992), described this part of the basin as a hemi-graben with NNW-SSE anthitetic normal faults and NE-SW transfer faults, mostly of dextral type. The normal faults form an imbricate, listric fan, plunging toward the east, and developed through foot-wall collapse by oblique $\mathrm{N} 50^{\circ} \mathrm{E}$ extension. According to Fleicher (1998), all these observations on the tectonic of the Sanfranciscana Basin fit very well into a model of successive small grabens filled with sediments.

\section{STRATIGRAPHY OF THE BASIN AREADO GROUP ABAETÉ FORMATION \\ It is represented mainly by conglomerates and sandstones, formed in desert environments. It was} here divided in two facies:

Carmo Facies Was deposited by alluvial fans or torrential fluvial streams of wadi-type, in the southern part of the basin, near scarps of the south and southwestern borders of the basin. It consists of a $9 \mathrm{~m}$ of maximum thickness of petromictic rock, matrix-supported, formed mainly by fragments of pebbles or cobbles of metasiltstone, quartz, quartzite, limestone, silcrete and granitoid rocks. The rock displays transported ventifact-like clasts. Its matrix is formed by rounded fragments of metasiltstone of sand-size, locally cemented by authigenic calcite.

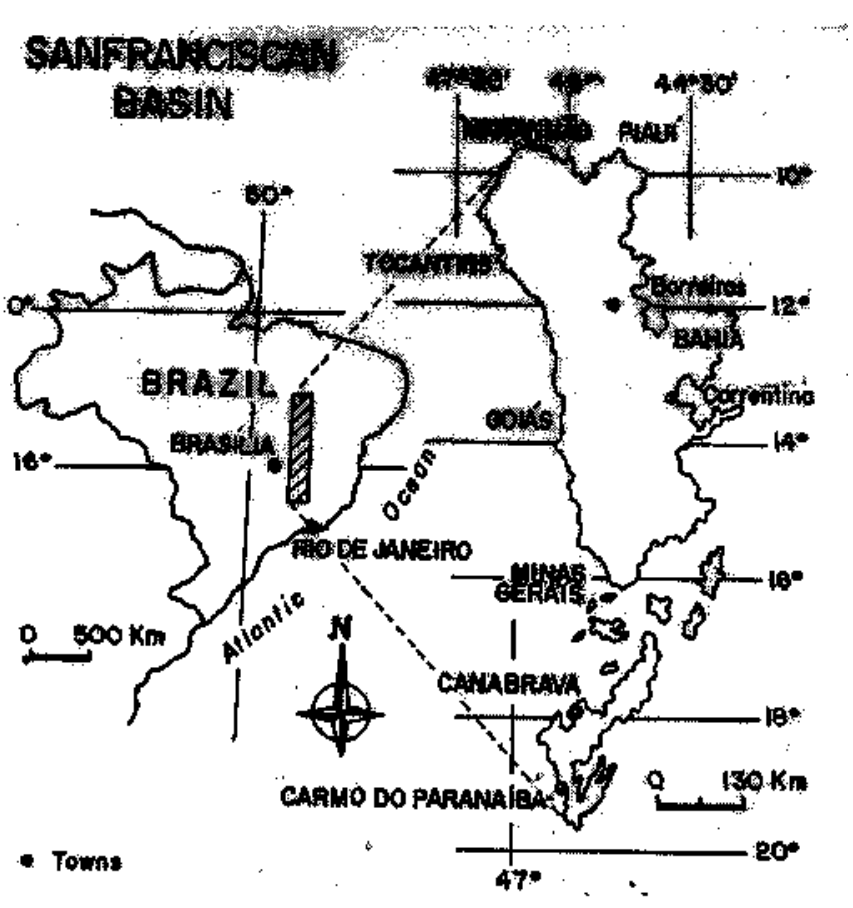

Figure I

The sedimentation filled depressions, in arid or semi-arid climate. Its origin is related to a Jurassic-Cretaceous regional uplift which affected and old and extensive denudation surface of the Gondwanaland, stabilized since the early Triassic. In the southern part of the basin it thickness varies from a few decimeters to a maximum of 8 meters. Cross-bedding in associated sandstone indicates a paleoflow direction approximately from south to north. Locally this conglomerate is affected by north-south inverse faults showing tectonic vergence toward east, from the Alto do Paranaíba Uplif to the São Francisco Craton. The top of the conglomerate is normally covered by a level of caliche of hard-pan type with plant microfossils.

Canabrava Facies This facies represents a northern continuity of the basal conglomerates of the Carmo Facies. It was developed in a flatter surface than the Carmo's area and the deposits were formed by a very large fluvial braided system, in the central part of the basin. It is a clast-supported conglomerate, with very well-rounded pebbles and 
cobbles of quartzite, with lenses of red sandstones associated. Directional structures like imbrication of clasts and cross-bedding in sands and gravels also indicate sense of paleoflow approximately from south to north. This conglomerate seems to have a low diamond content. Tompkins and Gonzaga (1989), Gonzaga et al. (1994) and Campos and Dardenne (1995) suggest that these gems were originated from the São Francisco Craton, positioned underneath and at the eastern side of the basin. These gems would have been transported to the basin by late Proterozoic and Permian-Carboniferous glaciation events.

The maximum thickness is $40 \mathrm{~m}$ near Canabrava town. General geologic features of this conglomerate were reported by Campos and Dardenne (1994). In the north, between the latitudes $11^{\circ} \mathrm{N}$ and $10^{\circ} \mathrm{N}$, this facies also exhibits a poor content in diamont (Chaves 1991).

QUIRICÓ FORMATION These Aptian lacustrine sediments cover a large area of occurrence, from south to north. They are fine-grained sandstones, mudstones, marls and limestones with intercalated caliche levels of hardpan type.

They have a maximum thickness of $60 \mathrm{~m}$ and are rich in depositional structures and syngenetic deformations. The fossiliferous content are ostracoda (Barbosa et al 1971; Sgarbi 1989,1997; Arai et al. 1995), conchostraca faunulas (Cardoso 1971), plant remains and pollens (Duarte 1968; Arai et al. 1995) and fishe-bones fragments of Dastilbe Moraensi ( Santos 1955,1985). Carvalho et al. (1995) described bone fragments of Coelacanth Mawzonia, a freshwater and giant fish which represents, after Wenz (1980), the third occurrence in Brazil. There are also four occurrences in Africa and this fact is an important indication of the faunal identity between Brazil and Africa during early Cretaceous.

Chemical analysis indicate that these lacustrine sediments have negative correlation between $\mathrm{SiO}_{2}$ and $\mathrm{CaO}$, and the generally high $\mathrm{B}$ $(180 \mathrm{ppm})$ contents suggest a shallow lake with high evaporation rate. Carbon and oxygen isotope data of carbonates $\left(\mathrm{d}^{18} \mathrm{O}\right.$ between -1.0 $\%$ and $+1.0 \% \mathrm{o}$ and $\mathrm{d}^{\mathrm{H}} \mathrm{C}$ between $-2.0 \%$ oo and $-2.5 \%$ oo ) also indicate also that the sediments were formed in a continental evaporitic lake, with decrease in salinity from the bottom to the top of the sequence (Sgarbi et al. 1993).

\section{TRÊS BARRAS FORMATION}

Its is divided in aeolian and fluviodeltaic sandstones. The fluviodeltaic terms occur as small Gilbert-like deltaic bodies superimposed on the lacustrine Quiricó sequence, with $20-30 \mathrm{~m}$ of maximum thickness. The cross-bedding assembly shows sense of transport from NE to SW and the sandstones exhibit a poorly-sorted, fine to medium-grained framework in a mudsize interstitial ground mass. They have a subarkose modal composition and and exhibit the presence of K-feldspar overgrowths (sanidine and adularia) developed in detrital microcline and orthoclase assembly (Sgarbi 1989, De Ros et. al. 1994, Sgarbi 1996). Bulk chemical analyses by ICP show that the rock have a abnormally high potassium content, the compositional $\mathrm{Na}_{2} \mathrm{O} / \mathrm{K}_{2} \mathrm{O}$ ratio is very low and lies ouside the range for typical subarkose and arkose reported in the literature (Sgarbi and De Ros 1994).

The eolian sandstones have a maximum thickness of $70 \mathrm{~m}$. Large tangential base cross-beddings show the direction of transport from south to north and from west to east It is formed by well-rounded medium size of frosted quartz and K-feldspar grains, exhibiting a wellsorted and bimodal granulometric distribution.

They also show, as the fluviodeltaic sandstones of this Formation, extensive cementation by authigenic K-feldspar (Sgarbi 1996).

Kattah (1991) registered the occurrence of a radiolarian fauna and sponge spicules, in thin levels of chert intercalated in these eolian sandstones. How marine fossils are present into a continental sequence in central Brazil? It is a surprising geologic puzzle, with many and large paleogeographic implications, with interest for the geology of the Gondwana and the opening of the South Atlantic ocean. To answer the question Pessagno and Dias-Brito (1996) and Dias-Brito et al.(1999) have made considerable efforts to elucidate this question; however the problem still persists.

\section{MATA DA CORDA GROUP PATOS FORMATION It is the}

basal unit of the Group and consists of ulbrabasic, alkaline, potassic to ultrapotassic lavas dated (at 80-87 My $\left({ }^{40} \mathrm{~K} /{ }^{40} \mathrm{Ar}\right.$ ) (Hasui and Cordani 1968, Ulbrich and Gomes 1981), compatible to $\mathrm{Ar}^{40} / \mathrm{Ar}^{39}$ data reported by Gibson et al. (1995). The lava crops out in the southern part of the basin as discontinuous small flow which are commonly highly weathered. The presence of kalsilite in these rocks (Sgarbi 1991, Sgarbi and Valença 1993) makes these rocks chemically and petrographically close to the kamafugitic rocks of Toro-Ankole, SW Uganda and San Venanzo area, Italy.

This volcanic alkaline province of the Sanfranciscan Basin also includes intrusive associations of kimberlite, carbonatite and lamproite (Leonardos and Meyer 1991, Leonardos et al. 1991, Bizzi 1993).

The area where the Areado and Mata da Corda Group occur represents one of the most important diamond provinces of the country, the Alto do Paranaíba Province. The Patos volcanism seems to have been the responsible for the diamonds historically found in this province in recent fluvial deposits, and exceptionally in late Cretaceous sedimentary rocks of the Romaria Mine. Corroborating this idea, the first diamond prospect of the country in kimberlitic rocks - the Serra da Canastra pilot plant - was recently opened in the region (Jornal Alto São Francisco, 1999).

Capacete Formation It consists of epiclastic conglomerates and sandstones deposited by alluvial fan and fluvial streams , and pyroclastic rocks, which occurs in the southern part of the basin. These rocks are mainly represented by weathering products of the volcanic rocks of the Patos Formation.

These rocks, with a maximum thickness of $150 \mathrm{~m}$ form the upper portion of the Mata da Corda Plateau, a extensive and flattened surface actually worked for large scale agriculture devices. The soil originated contain large amounts of maghemite former magnetite, present as reservoir of micro-nutrients for the plants (Ferreira et al. 1995; Silva et al. 1995)

Urucuia Formation It consists of muddy sandstones formed in fluvial and lacustrine environments, with intercalated conglomerate lenses and mud levels. Eolian sandstones were described too. The Formation also displays conglomerate with ventifacts deposited in an arid climate and overlies the Areado Group. It shows in the central do northern parts of the basin, a maximum thickness of $360 \mathrm{~m}$ (western Bahia State). This sequence is unfossiliferous and there is not any dating focussing it.

This basal conglomerate (as the Canabrava Facies of the Abaete Formation) is diamond-bearing, however, at very low grades. Braun. (1970) and Grossi Sad et al. (1971) have interpreted this sequence as a lateral facies variation of the Capacete Formation of the Mata da Corda Group, based in the regional geomorphologic pattern. On the other hand, Pedrosa Scares et al. (1997) interpreted this Formation as an individual sedimentary sequence, not belongin to the Areado and Mata da Corda Groups.

However, investigations focusing this sequence in northern Minas Gerais (this paper) have shown that there is no differences between this Formation and the Areado Group. Their geomorphologic patterns, lithologic association and sedimentary environments are the same of the Areado Formation. No unconformity was observed between them and they probably form the same chronostratigraphic unit Corroborating this point of view, Campbell et al. (1942) and Borges (1991), did not describe any clear disconformity in these sediments studied in a northern area of the basin.

\section{CORRELATIVE CRETACEOUS CONTINENTAL DEPOSITS}

IN BRAZIL AND AFRICA Sedimentary sequences similar to the ones of the Sanfranciscana Basin occur in the western and central parts of the African Continent (Angola, Zaire and Central African Republic). Both areas probably have similar geotectonic origin. Ages and lithologies are also similar. According to Chaves (1991), the correlative sequences are:

a) Early Cretaceous Continental Intercalate System (Angola) and Lualaba Series (Congo), (prekimberlite magmatism of the region), are formed by sediments of fluvial and lacustrine environments, and are similar to the Areado Group (also prealkaline-ultramafic magmatism of the Sanfranciscan Basin).

Late Cretaceous Calonda Formation (Angola) and Kwango Series (Central African Republic), (post-kimberlite magmatism of the region), are formed by a basal epiclastic and diamontiferous conglomerate of alluvial-fan or fluvial-lacustrine origin, and are similar to the Capacete Formation of the Mata da Corda Group (also postalkaline magmatism of the Sanfranciscan Basin).

Acknowledgments The Research funds of the Federal University of Minas Gerais (UFMG) provided the financial support (Project PRPq ET- 46, 1999) and FAPEMIG (Cex-1324/ 98). The author thanks to J.F.M.R. Albuquerque and F.J.BAARS (Cape Town University) for discussions and suggestions. 


\section{References}

ARAI, M.; DINO.R.; MILHOMEM, P.da S.; SGARBI, G.N.C., 1995. Micropaleontologia da Formação Areado, Cretaceo da Bacia Sanfranciscana: Estudos de ostracodes e palinologia. XIV Congr. Bras. Paleont., Uberaba, p.2-3.

BARBOSA, 0., BRAUN, O.P.G., DYER, R. C., CUNHA, C.A.B.R., 1971. Geologia da regiao do Triângulo Mineiro. Boletim D.N.P.M., Rio de Janeiro, v. 136,140p.

BIZZI,L.A.,1993. Mesozoic alkaline volcanism and mantle evolution of southwestern São Francisco craton, Brazil. PhD Thesis, Un.Cape Town, South Africa, 240 p.

BORGES, M.daS.; IGREJA, H.L.S.da; COSTA, J.B.S.; HASUI, Y; 1992. Faciologia e tectônica da Formação Urucuia na região de Dianópolis, SW de Tocantins. Geociências, 11(1)7-18

BRAUN, O.P.G. 1970. A Formação Areado e a Formação Serra Negra. Rev.Esc.Minas Ouro Preto,28(3):100-106.

CAMPBELL,D.F.,ALMEIDA.L.A.,SILVA,S.de 0,1949. Relatório preliminar sobre $a$ geologia da bacia do Maranhão. Bol. no. 1, Cons.Nac.Petroleo, RJ, p. 1-64

CAMPOS, J.E.G. \& DARDENNE, M.A., 1994. O sistema fluvial entrelacado dos conglomerados e arenitos do Membro Abaete na regiao de Canabrava, MG. Ill Simpósio sobre o Cretáceo do Brasil, p. 185-187.

CARDOSO, R.N., 1971. Contribuição ao estudo do Grupo Areado. Estratigrafia e descrição dos filópodos fósseis. UFMG, Mus.Hist.Nat., v.1, 56 p.

CARVALHO, M.S.S.de; ALMEIDA-CAMPOS, D. de; DARDENNE, M.A., SGARBI, G.N.C.S., CAMPOS, J.E.G.; CARTELLE, C., 1995. Coelacanths from the Lower Cretaceous of Minas Gerais, Brazil. XIV CONGR. BRAS. PALEONT., Uberaba, p.35.

CHAVES, M.L.de S.C.., 1991. Sequências cretácicas e mineralizações diamantíferas no Brasil Central e Africa Central Meridional. Considerações preliminares. São Paulo, Brasil Central e Africa Cente.

DE ROS, LF.de, SGARBI, G.N.C., MORAD, S., 1994. Multiple authigenesis of K-feldspar in sandstones: evidence from the Cretaceous Areado Formation, São Francisco Basin, Central Brasil. Jour, of Sedimentology Research, Vol. A64, No.4, p. 778-787.

DIAS-BRITO,D.,PESSAGNO,E.P.Jr.,CASTRO,J.C.,(1999). Novas considerações cronoestratigráficas sobre o silexito a radiolários do sul da Bacia Sanfranciscana, Brasil, e a ocorrência de foraminíferos planctonicos nestes depósitos. Bol V Simp.sobre o Cretáceo do Brasil, UNESP, p.567-575.

DUARTE, L. 1968. Restos vegetais fósseis da Formação Areado. XXII Congr.Bras.Geol., Belo Horizonte, p. 68

FERREIRA, B.A.; JESUS-FILHO, M.F.de; GOULART, A.T.; FABRIS, J.D.; PINTO, M.C.F., 1995. Caracterização químico-mineralógico de um perfil de solo magnético desenvolvido de basalto. 18a. Reun.Soc.bras.Química, Caxambu, MG, FQ-037.

FLEICHER,R.,1998. A rift model for the sedimentary diamond deposits of Brazil. Miner.Deposita, 33:238-254

GIBSON,S.A., THOMPSON,R.N., LEONARDOS.O.H., MITCHELL, J.G., 1995. The late Cretaceous impact of the Trindade Mantle Plume: evidence from large volume, mafic potassic magmatism in SE Brazil. Journ.Geology, 36(1); 189-229.

GONZAGA, G.M., TEIXEIRA, N.A., CASPAR, J.C., 1994. The Origem of Diamonds in Western Minas Gerais, Brazil. Mineralium Deposita, 29:414-421

GROSSI SAD, J.H., CARDOS, R.N., COSTA, M.T.da, 1971. Formações cretácicas em Minas Gerais: uma revisão. Rev.Bras.Geoc., 1:1-13.

HASUI,Y \& CORDANI.U.G., 1968. Idades K-Ar de rochas eruptivas mesozoicas do oeste mineiro e sul de Goias. XXII Congr.Bras.Geol., Belo Horizonte, p.139-143.

HASUI, Y.\& HARALYI.N.L.E., 1991. Aspectos lito-estruturais e geofísicos do soerguimento do Alto Paranaíba. Geociências, 10:57-77.

KATTAH.S.da S., 1991. Análise faciológica e estratigráfica do Jurássico Superior/Cretáceo Inferior na porção meridional da Bacia Sanfranciscana, oeste do Estado de Minas Gerais (M.Sc.Thesis,UFOP, $227 \mathrm{p}$

LEONARDOS, O.K. \& MEYER.H.O.A., 1991. Outline of the geology of western Minas Gerais. Fifth Int.Kimberlite Conference, CPRM Spec.Publ. 3/91. Brasflia, p. 17-21.
LEONARDOS, O.H., ULBRICH M.N., CASPAR, J.C., 1991. The Mata da Corda volcanic rocks. Fifth Int.Kimberlite Conference, CPRM Spec.Publ. 3/91.Brasilia, p.65-73. PEDROSA SCARES A.C., DARDENNE, M.A., HASUI,Y.,CASTRO,F.D.C.de, CARVALHO.V.V.A.de, 1994. Nota explicativa dos mapas geológico, metalogenetico e de ocorrencias minerais do estado de Minas Gerais. Esc. 1:000.000 Belo Horizonte:Comig, $97 \mathrm{p}$.

PESSAGNO, E.A.Jr. \& DIAS-BRITO, D., 1996. 0 silexito a radiolarios ao sul da Bacia Sanfranciscana, Brasil. Idade, origem, significado. Bol.FV Simp sobre o Cretáceo do Brasil, Rio Claro, Unesp, p. 213-221.

SANTOS, R. da. S., 1955. Ocorrência de folhelho fossilifero cretácico no município de Presidente Olegario, Minas Gerais. Boletim D.N.P.M., Rio de Janeiro, v. 155,27p.

SANTOS, R.da S., 1985. Laeliichthys Ancestralis, novo gênero e espécies de Osteoglossiformes do Aptiano da Formação Areado, Estados de Minas Gerais, Bra-

sil. MME-DNPM, sen Geologia no.27, p.161-167.

SCHOBBENHAUS,C.;CAMPOS,D.A.;DERZE,G.R.;ASMUS,H.E.(Coords.)(1981)Map geológico do Brasil. Rio de Janeiro, DNPM/PETROBRAS, 4 folhas, esc. 1:2 500 000 .

SGARBI,G.N.C.,1989. Geologia da Formação Areado: Cretáceo Inferior a Médio da Bacia do São Francisco, oeste do Estado de Minas Gerais. M.Sc.Thesis, Universidade Federal do Rio de Janeiro-UFRJ, $324 \mathrm{p}$.

SGARBI, G.N.C. 1991. Arenitos eól icos da Formação Areado (Bacia do São Francisco): Caracterizacão, diagenese e aspectos químicos. Rev.bras.Geoci., 21(4):342-354.

SGARBI.G.N.C, 1996. Investigação sub-microscopica (MEV.MSE) em arenitos cretácicos da Bacia Sanfranciscana, oeste de. M.G. Geoch. Brasiliensis 10(1):175-179.

SGARBI, G.N.C., 1999. Rochas vulcanoclasticas do Cretaceo Superior no Oeste de Minas Gerais, lo Simpósio Sobre Vulcanismo e Ambientes Associados. Gramado, RS, p.

SGARBI, G.N.C. \& DE ROS, L.F. de. 1994. Petrological and chemical aspects of Kfeldspar authigenesis in the Cretaceous Areado Sandstones. Bol.III Simp, sobre o Cretáco no Brasil, p. 193-196, UNESP, Rio Claro, São Paulo.

SGARBI, G.N.C., HORN,H.A.;GROSSI SAD, J.H, 1993. Aspectos químicos e isotópicos dos sedimentos lacustres da Formação Areado, Bacia Cretacica do São Francisco, MG.An.Acad.bras.Ci.,65(3):265-270

SGARBI, P.B.de A., 1991. Petrografia e geoquímica da Fm.Mata da Corda na região de Carmo do Paranaiba, oeste de Minas Gerais. Dissertação de Mestrado, UFRJ, 214

SGARBI,P.B.de A.\& VALENCA,J.G.,1993. Kalsilite in Brazilian kamafugitic rocks. Mineral.Magazine, 57:165-171.

SILVA, H.R.de.C; GOULART, A.T ; SGARBI, G.N.C. SANTANA, G.P.; JESUS-FILHO, M.F.de., 1995. Estudo Mossbauer de sedimentos vulcânicos do Cretáceo Superior da Bacia Sanfranciscana. 18a. Reun. Soc.bras.Química, Caxambu, MG, FQ-038.

TOMPKINS, LA., GONZAGA.G.M., 1989. Diamonds in Brazil and a proposed model for the origin and distribution of diamonds in the Coromandel region, Minas Gerais, Brazil. Econ.Geol., 84:591-602.

ULBRICH, H.H.G.J.\& GOMES, C.B., 1981. Alkaline rocks from continental Brazil. Earth Sci.Reviews, 17:135-154.

WENZ,S. 1980. A propos du genre Mawzonia, Coelacanthe geant du Cretace inferieur d'Afrique et du Bresil. Mem. Soc. Fr.,N.S., 139:187-190.

Contribution IGC-146

Rentribution IGC-146 Accepted for publication May 10, 2000 